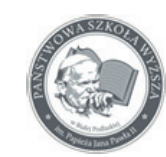

Authors' contribution/

Wkład autorów:

A. Zaplanowanie badań/

Study design

B. Zebranie danych/

Data collection

C. Analiza statystyczna/

Statistical analysis

D. Interpretacja danych/

Data interpretation

E. Przygotowanie tekstu/

Manuscript preparation

F. Opracowanie

piśmiennictwa/

Literature search

G. Pozyskanie funduszy/

Funds collection
ISSN 2083-3725

Volume 10, No. 3, 2017

\section{REVIEW OF THE BOOK BY AGATA BALIŃSKA TITLED "THE IMPORTANCE OF TOURISM IN THE DEVELOPMENT OF RURAL COMMUNITIES BASED ON THE EXAMPLE OF THE PERIPHERAL AREAS OF THE EASTERN BORDERLAND OF POLAND" SGGW PUBLISHING HOUSE, WARSAW 2016, P. 300}

\author{
RECENZJA KSIĄŻKI AGATY BALIŃSKIEJ PT. „ZNACZENIE TURYSTYKI W \\ ROZWOJU GMIN WIEJSKICH NA PRZYKŁADZIE OBSZARÓW PERYFERYJNYCH \\ WSCHODNIEGO POGRANICZA POLSKI" \\ WYDAWNICTWO SGGW, WARSZAWA 2016, S. 300
}

\section{Izabella Sikorska-Wolak}

Pope John Paul II State School of Higher Education in Biała Podlaska

Państwowa Szkoła Wyższa im. Papieża Jana Pawła II w Białej Podlaskiej

Sikorska-Wolak I. (2017), Review of the book by Agata Balińska titled "The importance of tourism in the development of rural communities based on the example of the peripheral areas of the eastern borderland of Poland”/Recenzja książki Agaty Balińskiej pt. „Znaczenie turystyki w rozwoju gmin wiejskich na przykładzie obszarów peryferyjnych wschodniego pogranicza Polski". Economic and Regional Studies, vol. 10, No. 3, pp. 108-112. https://doi.org/10.2478/ers-2017-0029
The book is a scientific monograph. It is a comprehensive theoretical and empirical study of the role and perspectives of tourism development in peripheral areas of the eastern borderland of Poland. The issues raised are interesting both from the theoretical and the application point of view. They are important for the development of rural areas, especially the eastern border areas, which are characterized by the peripheral nature of socioeconomic development, and yet possess valuable, not yet fully exploited resources. Although rural development with the use of the tourist function became the subject of scientific research already in the 1990s (along with the realization of the concept of multifunctional rural development), the rapidly changing socio-economic reality triggers a need for continuous monitoring of occurring changes. In addition, these were mostly introductory studies, usually limited to individual local territorial units, whereas the research itself was predominantly descriptive. The reviewed work is characterized by an in-depth and multi-faceted view of the issues raised, linking theoretical issues, with the use of a wide range of the current research results contained in source literature, with the results of the author's own empirical research. Undoubtedly, the value of the monograph is thus its comprehensive, theoretical and empirical depiction of the issue of the importance of
Książka ma charakter monografii naukowej. Jest to obszerne studium teoretyczno-empiryczne dotyczące roli i perspektyw rozwoju turystyki na obszarach peryferyjnych wschodniego pogranicza Polski. Podjęta problematyka jest interesująca zarówno z teoretycznego jak i aplikacyjnego punktu widzenia. Jest ważna dla rozwoju obszarów wiejskich, a w szczególności wschodnich obszarów przygranicznych cechujących się peryferyjnością rozwoju społeczno-gospodarczego, ale posiadających wartościowe, niewykorzystane dotychczas w pełni zasoby. I chociaż rozwój obszarów wiejskich z wykorzystaniem funkcji turystycznej stał sie przedmiotem badań naukowych jeszcze w latach 90. ubiegłego wieku (wraz z urzeczywistnianiem koncepcji wielofunkcyjnego rozwoju wsi) to zmieniająca się w szybkim tempie rzeczywistość społeczno-gospodarcza wyzwala potrzebą ciągłego monitorowania zachodzących zmian. Poza tym były to w większości badania przyczynkarskie ograniczające się najczęściej do pojedynczych jednostek terytorialnych szczebla lokalnego., zaś w badaniach dominował opis. Recenzowana praca odznacza się pogłębionym i wieloaspektowym ujęciem podjętej problematyki, powiązaniem zagadnień teoretycznych $\mathrm{z}$ wykorzystaniem szerokiego przeglądu dotychczasowego dorobku zawartego w literaturze przedmiotu z wynikami własnych badań empirycznych Autorki. Niewątpliwym więc walorem

Address for correspondence/ Adres korespondencyjny: prof. nadzw. dr hab. Izabella Sikorska-Wolak, Państwowa Szkoła Wyższa im. Papieża Jana Pawła II w Białej Podlaskiej, Wydział Nauk Ekonomicznych i Technicznych, ul. Sidorska 95/97, 21-500 Biała Podlaska, Poland; phone: +48 83 344-99-05; e-mail: izabella_sikorska_wolak@sggw.pl

Journal indexed in/ Czasopismo indeksowane w: AgEcon Search, AGRO, BazEkon, Index Copernicus Journal Master List, ICV 2016: 92,91; Polish Ministry of Science and Higher Education 2016: 9 points / AgEcon Search, AGRO, BazEkon, Index Copernicus Journal Master List ICV 2016: 92.91; Ministerstwie Nauki i Szkolnictwa Wyższego 2016: 9 punktów. Copyright: (C) 2017 Pope John Paul II State School of Higher Education in Biała Podlaska, Izabella Sikorska-Wolak. All articles are distributed under the terms of the Creative Commons Attribution-NonCommercial-ShareAlike 4.0 International (CC BY-NC-SA 4.0) License (http://creativecommons.org/licenses/by-nc-sa/4.0/), allowing third parties to copy and redistribute the material in any medium or format and to remix, transform, and build upon the material, provided the original work is properly cited and states its license. 
tourism in the development of rural communities.

Analysis of source literature, knowledge of the problems in the development of rural communities located in the peripheral areas of the eastern borderland and extensive research experience regarding the problems of rural tourism development allowed the author to accurately formulate three research hypotheses. They are connected with the main purpose of the work, which was to define theoretical foundations for the development of tourism in the rural peripheral area of the eastern borderland of Poland and its role in the development of the local environment (local territorial units). Specific objectives, of cognitive (3 objectives), methodological ( 2 objectives) and application nature (3 objectives), contributed to its implementation. The objectives were appropriately formulated. The research methodology was presented in a detailed and transparent manner in the introductory part of the work. The strength of the monograph lies in the multitude of the research material sources used in it. The first type are secondary sources, including: a wide range of national and foreign academic literature, legal acts, planning documents of strategic nature for regional and local development, studies of national and regional official statistics. The second type is the author's own research conducted in 2006 and 2012 among two opinion-forming groups, i.e. owners of rural tourism facilities (160 people) and inhabitants of villages not involved in tourism activities (600 people) in 12 selected border municipalities of Lublin and Podlaskie provinces. Owing to the limitation of the geographic scope of the research, it was possible to show the specific character of this area resulting from the nature of the border and the role of tourism in its development, among others. The presented research approach enabled equal treatment of both the descriptive and the explanatory research, as well as making a comparative analysis of the examined territorial units and phenomena in temporal and spatial approach.

The structure and the thematic scope of the work are subordinated to achieving the objectives and verifying the research hypotheses. The monograph consists of an introduction, six substantive chapters, a summary and a conclusion, capacious bibliography containing 487 entries. The wide range of works cited is justified as the examined problem is interdisciplinary and predominantly economic and the author tried to elucidate it from the position of various scientific disciplines. The annex (27 appendices) is an important part of the work. In the monograph, two main interwoven layers and parts of the work corresponding to them can be distinguished: a theoretical-cognitive one and an empirical-application one. The first part, entitled "The Theoretical Foundations for the Development of Peripheral Rural Municipalities Including the Tourism Function" (chapters 1-3) is a review, while in the second, research and empirical, part, entitled "The Role of Tourism in the Development of Rural Municipalities in the Eastern Borderland of Poland Research Results" (chapters 4-6), the author presents monografii jest całościowe, teoretyczne i empiryczne ujęcie problematyki znaczenia turystyki w rozwoju gmin wiejskich.

Analiza literatury przedmiotu, znajomość problemów rozwoju gmin wiejskich położonych na obszarach peryferyjnych wschodniego pogranicza oraz duże doświadczenie badawcze nad problemami rozwoju turystyki na terenach wiejskich pozwoliły $\mathrm{Au}$ torce na trafne sformułowanie trzech hipotez badawczych. Wiążą się one z głównym celem pracy którym było określenie teoretycznych podstaw rozwoju turystyki na wiejskim obszarze peryferyjnym wschodniego pogranicza Polski i wskazanie jej roli w rozwoju środowiska lokalnego (jednostek terytorialnych szczebla lokalnego). Jego realizacji służyły cele szczegółowe o charakterze poznawczym (3 cele), metodycznym ( 2 cele) i aplikacyjnym ( 3 cele). Cele te zostały trafnie sformułowane. Metodyka badań przedstawiona została w sposób szczegółowy i przejrzysty w części wstępnej pracy. Mocną stroną monografii jest wielość wykorzystywanych w niej źródeł materiału badawczego. Pierwsze to źródła wtórne, obejmowały one: bogatą literaturę naukową krajową i zagraniczną, akty prawne, dokumenty planistyczne o charakterze strategicznym dotyczące rozwoju regionalnego oraz lokalnego, opracowania statystyki publicznej krajowej i regionalnej. Drugie to własne badania $\mathrm{Au}-$ torki przeprowadzone w latach 2006 i 2012 wśród dwu grup opiniotwórczych, tj. właścicieli obiektów turystyki wiejskiej (160 osób) oraz mieszkańców wsi niezaangażowanych w działalność turystyczną $(600$ osób) na terenie 12 wybranych gmin przygranicznych województwa lubelskiego i podlaskiego. Dzięki ograniczeniu zasięgu geograficznego badań możliwe było ukazanie specyfiki tego obszaru wynikającej m.in. z charakteru granicy i roli turystyki w jego rozwoju. Zaprezentowane podejście badawcze umożliwiło równorzędne potraktowanie badań opisowych i wyjaśniających oraz dokonanie analizy porównawczej badanych jednostek terytorialnych i badanych zjawisk w czasie i przestrzeni .

Konstrukcja i zakres tematyczny pracy podporządkowane są realizacji celów oraz weryfikacji hipotez badawczych. Monografia składa się z wprowadzenia, sześciu rozdziałów merytorycznych, podsumowania i wniosków, pojemnej bo liczącej 487 pozycji bibliografii. Szeroki zakres cytowanych pozycji literatury jest uzasadniony bowiem badany problem ma charakter interdyscyplinarny z przewagą nurtu ekonomicznego i Autorka starała się go oświetlić z pozycji różnych dyscyplin naukowych. Ważną częścią pracy jest aneks (27 załączników) W monografii wyodrębnić można dwie główne wzajemnie przenikające się warstwy i odpowiadające im części pracy: teoretyczno-poznawczą i empiryczno-aplikacyjną. Część pierwsza zatytułowana „Teoretyczne podstawy rozwoju wiejskich gmin peryferyjnych z uwzględnieniem funkcji turystycznej"(rozdziały 1-3) ma charakter przeglądowy, w części drugiej - badawczo - empirycznej zatytułowanej „Rola turystyki w rozwoju gmin wiejskich wschodniego pogranicza Polski - wyniki badań" (rozdziały 4-6) prezentuje Autorka wyniki własnych badań. Rezygnując w tym 
the results of her own research. Resigning here from the detailed description of the contents of each chapter, I would like to emphasize that its structure is coherent, logical, consistent with the principles of methodology and method application adopted in economic sciences. The first part of the work contains a comprehensive review of domestic and foreign literature within a range of tourism and development of local and regional units, competitiveness, innovativeness and entrepreneurship of local units, unique character of border areas (particularly the Eastern borderland of Poland), function of the border in the development of areas neighbouring Poland, position of tourism in the social and economic development of the areas, factors of development of municipalities with features of peripheral areas. This was preceded by the successful systematization of concepts connected with the peripheral areas and borderlands as well as the broad presentation of their basic features. The author shares the view that peripherality can be considered in at least two senses: geographical (distance from the centre) and economic (low level of economic development). Much attention is devoted to the problem of the competitiveness of spatial structures, pointing to the complexity of the term "competitiveness" in relation to tourism (sub-unit1.3). In many studies, as emphasised by the author, tourism assets (natural and cultural) are assumed as the basis of competitive potential, which, in her opinion, is not justified and has been emphasized in many of her publications released in recent years. Equally important is human capital - the ingenuity of tourist service providers, especially when supported by local authorities. It is worth pointing out how the evolution of the semantic concept and forms of competition are depicted and stressed from competition and rivalry (traditional approach) to the concept of collaboration and cooperation (contemporary approach). This particularly applies to territorial units of different levels of governance. So, the author when analysing the research problem in the context of the local development theory (sub-unit 1.2.), correctly emphasises the theory of endogenous development and the learning region in the course of its explanation. The following sections show various aspects of the competitiveness of peripheral areas. "Factors and Measurement of the Development of Municipalities with Features of Peripheral Areas" (unit2) and "Tourist Functions of rural areas" (unit3) are the titles of another extensive theoretical part of the monograph. This part of the work was written with great knowledge of the problems analysed. The author refers to both the classics laying the theoretical foundations of local development and the latest literature items dealing with this field. The author conducted a thorough analysis of the current research on the measure of local development and the summary of variables used by other authors to determine the socio-economic development of territorial units and proposed further research methodology on the problem of the development of rural municipalities with the use of the tourist function. What the authors should receive credit for and what constitutes the added value of this part of the work is the development miejscu ze szczegółowego opisu treści poszczególnych rozdziałów pragnę podkreślić, że jej struktura jest spójna, logiczna, zgodna z regułami metodologicznymi i metodycznymi przyjętymi w naukach ekonomicznych. Pierwsza część pracy zawiera szeroki przegląd krajowej i zagranicznej literatury z zakresu turystyki oraz rozwoju jednostek terytorialnych szczebla lokalnego i regionalnego, konkurencyjności, innowacyjności i przedsiębiorczości jednostek lokalnych, specyfiki terenów przygranicznych (w szczególności wschodniego pogranicza Polski), roli granicy w rozwoju sąsiadujących z nia terenów, miejsca turystyki $w$ rozwoju społeczno-ekonomicznym obszarów, czynników rozwoju gmin o cechach obszarów peryferyjnych. Poprzedzone to zostało udanym usystematyzowaniem pojęć związanych z peryferiami i pograniczami oraz szeroką prezentacją podstawowych ich cech. Autorka podziela pogląd, iż peryferyjność można rozpatrywać w co najmniej dwóch znaczeniach: geograficznym (oddalenie od centrum) i ekonomicznym (niski poziom rozwoju gospodarczego). Wiele miejsca poświęca Autorka problematyce konkurencyjności struktur przestrzennych, wskazując na złożoność pojęcia „konkurencyjność” w odniesieniu do turystyki (podrozdz.1.3). W wielu bowiem opracowaniach jak podkreśla Autorka jako podstawa potencjału konkurencyjnego przyjmowane są walory turystyczne (przyrodnicze i kulturowe) co w jej ocenie nie jest uzasadnione i co podkreślała w wielu swoich publikacjach ukazujących się w ostatnich latach. Równie bowiem ważny jest kapitał ludzki- pomysłowość usługodawców turystycznych, szczególnie gdy wspierana jest przez władze lokalne. Na podkreślenie zasługuje ukazanie i zaakcentowanie ewolucji znaczeniowej pojęcia i form konkurowania - od rywalizacji i współzawodnictwa (tradycyjne ujęcie) do koncepcji współpracy i współdziałania (współczesne ujęcie). Szczególnie odnosi się to do jednostek terytorialnych różnych szczebli zarządzania. Słusznie więc autorka analizując badana problematykę w kontekście teorii rozwoju lokalnego (podr. 1.2.), szczególnie podkreśla w jej wyjaśnianiu teorię rozwoju endogenicznego oraz regionu uczącego się. W kolejnych częściach pracy ukazuje różnorodne aspekty konkurencyjności obszarów peryferyjnych. „Czynniki i pomiar rozwoju gmin o cechach obszarów peryferyjnych" (rozdz.2) oraz „Funkcje turystyczne obszarów wiejskich" (rozdz.3) to tytuły kolejnej obszernej teoretycznej części monografii .Ta część pracy napisana została z dużym znawstwem analizowanej problematyki, Autorka odwołuje się w niej zarówno do klasyków tworzacych teoretyczne podstawy rozwoju lokalnego, jak i uwzględnia najnowsze pozycje literatury z tego zakresu. Dokonała rzetelnej analizy dotychczasowych badań nad pomiarem rozwoju lokalnego oraz zestawienia zmiennych wykorzystanych przez innych autorów do określenia stanu rozwoju społeczno-gospodarczego jednostek terytorialnych. Zaproponowała w dalszej części pracy metodykę badań nad problematyką rozwoju gmin wiejskich z wykorzystaniem funkcji turystycznej. Zasługą Autorki i wartością dodaną tej części pracy jest opracowanie zestawu syntetycznych wskaźników: pomiaru 
of a set of synthetic indicators: for measuring the level of local development, assessing the state of tourism potential and assessing the level of development of tourist and agritourism. The developed indicators apart from the high application value also have a great methodological value and can be used in research on the role of tourism in the development of rural municipalities (the author employed them in the empirical part of the work). The above chapters, of review character, are the background and point of reference for presenting the results of the author's own empirical research. Thus, the empirical part of the work has solid theoretical foundations.

The empirical part of the work begins with a chapter entitled "Factors and development level of investigated municipalities with special regard to tourist function", in which the author concentrates on presenting the characteristics of the studied peripheral area and analysing the indicators characterizing its socio-economic situation. By employing the taxonomic method, the author assessed and measured the socio-economic development of the investigated municipalities, making a good choice of the diagnostic variables in the assessment of the tourist potential of municipalities and the development status of the tourist function. This enabled her to rank the investigated municipalities in terms of the above indicators and to seek dependencies between local development and tourism potential indicators, tourist and agritourist functions, as well as the tourism potential indicator and the indicator of the tourist and agritourist function. By making comparisons using the correlation analysis between the level of local development and the state of tourist function development as well as tourism potential and the development of tourist function, the author arrives at interesting conclusions (unit4) The next two units (fifth and sixth) present the results of the author's own research using the questionnaire technique among two opinion-forming groups, i.e. rural accommodation providers and rural residents not involved in tourism operations. They referred to various aspects of tourism in border areas, such as elements of tourism potential, tourism organization, motivation for undertaking activities, knowledge and skills necessary to conduct tourism operations, sources of financing, scope of offer, forms and channels of promotion, instruments used to improve competitive position. In this part of the work, the author also draws attention to the benefits for the communes resulting from the border location, as well as the threats that may be posed by the proximity of the border, and also diagnoses the possibilities and barriers of the development of tourist functions in borderland communes. The empirical part of the work was written in a very professional manner, carefully refined in terms of statistics and interpretation of results. It offers a lot of interesting conclusions that are important both in the field of theoretical and practical-application knowledge.

In the summary of the work, the author (according to the methodological procedures) refers to goals and hypotheses, which were formulated in the poziomu rozwoju lokalnego, oceny stanu potencjału turystycznego oraz oceny poziomu rozwoju funkcji turystycznej i agroturystycznej. Opracowane wskaźniki poza dużą wartością aplikacyjną posiadają także dużą wartość metodyczną i mogą być wykorzystane w badaniach nad rolą turystyki w rozwoju gmin wiejskich (Autorka wykorzystała je w części empirycznej pracy). Powyższe rozdziały mające charakter przeglądowy stanowią tło i punkt odniesienia do prezentacji w dalszej części pracy wyników własnych badań empirycznych Autorki. Część empiryczna pracy posiada więc solidną podbudowę teoretyczną.

Część empiryczną pracy rozpoczyna rozdział zatytułowany "Czynniki i poziom rozwoju badanych gmin ze szczególnym uwzględnieniem funkcji turystycznej" na którego wstępie Autorka koncentruje się na zaprezentowaniu cech badanego obszaru peryferyjnego i analizie wskaźników charakteryzujących jego sytuację społeczno-ekonomiczną. Stosując metody taksonomiczne dokonała oceny i pomiaru rozwoju społeczno-ekonomicznego badanych gmin, w dalszej kolejności dokonując trafnego wyboru zmiennych diagnostycznych - oceny potencjału turystycznego gmin oraz stanu rozwoju funkcji turystycznej. Pozwoliło jej to na uszeregowanie badanych gmin pod względem w/w wskaźników oraz poszukiwanie zależności między wskaźnikami rozwoju lokalnego oraz potencjału turystycznego, funkcji turystycznej i agroturystycznej, a także wskaźnikiem potencjału turystycznego a wskaźnikami funkcji turystycznej i agroturystycznej. Dokonując porównań przy pomocy analizy korelacyjnej pomiędzy poziomem rozwoju lokalnego a stanem rozwoju funkcji turystycznej oraz poziomem potencjału turystycznego a rozwoju funkcji turystycznej dochodzi Autorka do interesujacej konkluzji i ciekawych wniosków (rozdz.4). Kolejne dwa rozdziały (piąty i szósty) prezentują wyniki własnych badań z wykorzystaniem techniki ankiety wśród dwóch grup opiniotwórczych, tj. wiejskich kwaterodawców oraz mieszkańców wsi niezaangażowanych w działalność turystyczną. Dotyczyły one różnych aspektów turystyki na obszarach przygranicznych, takich jak: elementy potencjału turystycznego, organizacji turystyki, motywów podejmowania działalności, wiedzy i umiejętności niezbędnych do prowadzenia działalności turystycznej, źródeł finansowania, zakresu oferty, form i kanałów promocji, stosowanych instrumentów poprawy pozycji konkurencyjnej. W tej części pracy Autorka zwraca też uwagę na korzyści gmin wynikające z przygranicznego położenia, jak równie zagrożenia jakie może stwarzać bliskość granicy, dokonuje też diagnozy możliwości i barier rozwoju funkcji turystycznej gmin przygranicznych. Część empiryczna pracy napisana została w sposób bardzo profesjonalny, jest starannie dopracowana pod względem statystycznym i interpretacji wyników. Dostarcza wiele interesujących wniosków mających znaczenie zarówno w zakresie wiedzy teoretycznej jak i praktyczno-aplikacyjnej.

W części podsumowującej pracy Autorka (zgodnie $\mathrm{z}$ procedurami metodologicznymi) odnosi się do celów oraz sformułowanych na wstępie hipotez. Formułuje też interesujące wnioski końcowe o cha- 
introduction. She also formulates interesting final conclusions of cognitive, methodological and application nature. The editorial side of the work should also be highly appreciated. The book is written in appropriate scientific language, with rich and varied terminology. The monograph by dr hab. A. Balińska is a very successful scientific study and is a valuable contribution to the theory - it significantly broadens, systematizes and clarifies knowledge about the role of tourism in the development of eastern peripheral areas and sets directions for further research. rakterze poznawczym, metodycznym i aplikacyjnym Wysoko ocenić należy też stronę edytorską pracy. Napisana ona jest poprawnym, bogatym w zasób słów językiem naukowym. Monografia dr hab. A. Balińskiej jest bardzo udanym opracowaniem naukowym i stanowi cenny wkład do teorii - znacząco poszerza, systematyzuje i porządkuje wiedze na temat roli turystyki w rozwoju wschodnich obszarów peryferyjnych oraz wyznacza kierunki dalszych poszukiwań badawczych. 